\title{
Emerging Challenges in the Completion of Construction Projects through Public Private Partnerships: Empirical Literature Review
}

\author{
Pamela Akinyi Oyieyo \\ School of Open and Distance eLearning, University of Nairobi, Nairobi, Kenya \\ Email: poyieyo@yahoo.com
}

How to cite this paper: Oyieyo, P.A. (2020) Emerging Challenges in the Completion of Construction Projects through Public Private Partnerships: Empirical Literature Review. Journal of Building Construction and Planning Research, 8, 263-272. https://doi.org/10.4236/jbcpr.2020.84017

Received: October 28, 2020

Accepted: December 19, 2020

Published: December 22, 2020

Copyright ( 2020 by author(s) and Scientific Research Publishing Inc. This work is licensed under the Creative Commons Attribution International License (CC BY 4.0).

http://creativecommons.org/licenses/by/4.0/

\begin{abstract}
The process of engaging private sector in the provision of public infrastructure can improve economic value in service delivery and enable the government to utilize the capabilities and expertise held by private sector. This has a positive impact on the public in terms of improving their well-being. This literature review attempts to compare the challenges encountered in implementation of PPP projects across the world, with a view to determining cross cutting challenges and recommendations for developing countries. A literature review was conducted for empirical studies focusing on construction projects. The studies are reviewed by analyzing the methodology used and conclusions made to identify the geographical study area, Public Private Partnership project financing model, emerging challenges and recommendation for future project management. The literature search was based on four keywords: construction projects, completion of construction projects, public private partnership, challenges in construction projects. Thus, a total of 11 empirical studies were identified for review in Europe, Asia and Africa. The review revealed that most risk factors affecting project completion can be categorized as human and organizational factors and unknown geotechnical conditions that were not known beforehand. Specifically, project owners' interference was also attributable to delays with the delays having significant implications for project execution. Risks have great impact on the performance of construction projects because they affect their quality, time and cost. The general remedy to such potential risk factors is adoption of reliable prediction mechanisms which would estimate those factors using a probabilistic model that does not rely on expert judgments as they tend to be unreliable.
\end{abstract}

\section{Keywords}

Construction Projects, Completion of Construction Projects, Public Private 
Partnership, Challenges in Construction Projects

\section{Introduction}

\subsection{Background}

Adoption of Public Private Partnership models in the delivery of public projects was seen as ideal for effective economic development in developing economies during 1990s [1]. Due to its perceived success, PPP is accepted and recommended worldwide as a tool for an efficient, transparent and effective strategy that guarantees value for money for public sector projects which had previously known persistent and consistent failure leading to disappointments. This was so much because the failure in the projects was attributed to wrong or poor choices of policies as well as bureaucracy [2]. The expansion of the public sector consequently ceased to be the automatic policy preference in most developing countries [1].

PPP refers to partnership involving government institutions to enter into with private investors in service delivery [3]. Private Sector Participation (PSP) largely emphasizes on transfer of contractual obligations to private sector as opposed to putting more emphasis on opportunities in partnership [4]. According to [5], the process of engaging private sector in the provision of public infrastructure can improve economic value in service delivery and enable the government to utilize the capabilities and expertise held by private sector. This has a positive impact on the public in terms of improving their well-being. In addition, it helps governments to share risks by transferring some to private investors who are engaged in intensive investment [6].

As projects' sizes increase so do their complexity. Accordingly, the ability to manage risks depends on the measures taken beforehand to prevent unwanted outcomes. Panthi, Ahmed and Ogunlana [7] claim that construction projects are unique and complex because it is almost not possible to evaluate their levels of risks. For this reason, it might not be possible to develop and apply the necessary risk management strategies. For instance, it is not possible to estimate the level of variation in the project that may impact project quality, time and costs. Accordingly, it is necessary to utilize contingency theory in construction projects as a way of minimizing variations that might occur during project implementation. Even though different risks are evaluated in this study, special attention is given to contingency cost. Delays and excess costs are influential in construction works; as such, they might influence their lifetime. Normally, these types of projects have extensive bidding processes that require a competitive estimation of appropriate costs. This explains the importance of contingency theory in such projects.

Recently, there have been intense discussions at various platforms relating to the way governments can partner with private sector to provide services and in- 
frastructures like railways, roads, water, sanitation, Housing, Harbor, and Airport [8]. In decision-making processes, accurate estimates of risks and uncertainties are essential because they help in addressing some of the challenges beforehand. An extensive construction project is generally a large system combined with many factors, management levels, relations and participants. As such, diverse management risks may arise out of it because of diversity in targets, people and resources and even interests that might differ in some instances.

\subsection{Purpose}

This literature review attempts to compare the challenges encountered in implementation of PPP projects across the world, with a view to determining cross cutting challenges and recommendations for developing countries.

\section{Literature Review}

For unknown risks, there is low understanding on probability of occurrence and ultimate impact [9]. As a result, the functions of those involved in managing projects should be to foresee risks and device mechanisms to mitigate them and organize activities so that projects would be completed in good time [10]. Thus, both public and private sectors should establish efficient strategies for allocating risks to negotiate effectively in PPP contracts [11]. Because of financial, political, and social factors, projects which are construction related in varying geographically areas across the world are vulnerable to delays [12]. The delays can be avoided if the sources of those factors would be identified.

Researchers have shown that contractors fail to make use of risk analysis techniques and instead depend on own judgments as they estimate cost and time. A study by [13] in Tanzania has shown that project owners and consultants tend to lack innovative methods of preventing and mitigating risks. Similarly, [14] asserts that assessment of risk of rising costs and working within budget guidelines is also a for construction projects in Ugandan. This has increased project cost, delayed projects and even lessened the quality of projects. As members of the East African Common Market, the risks affecting construction projects in Uganda are identically similar to the risks in Kenya.

Risks can increase losses by increasing costs, undermining the quality of projects, and even delaying delivery of designed works. Tipili and Ilyasu [14] highlighted that the main challenge that faced construction in Nigerian was timely delivery and cost compliance. Utility in the infrastructure projects that have been completed in the last few years has increased their prices [15].

\section{Methodology}

In this paper, a literature review was conducted for empirical studies focusing on construction projects. The aim is to establish and categorize challenges faced in the implementation of construction projects through PPP model with emphasis on the developing countries. Thus, the studies are reviewed to show the geo- 
graphical study area, project financing model, emerging challenges and recommendation for future project management. The literature search was based on four keywords: construction projects, completion of construction projects, public private partnership, challenges in construction projects. Thus, a total of 11 empirical studies were identified for review in Europe, Asia and Africa based on the keywords and for the period covering the year 2000 to present. Thus challenges were identified based on prevalence and their effect. The findings of the review were presented in literature discussions.

\section{Results and Discussions}

Based on the four keywords, 11 studies were identified for completed PPP projects for the period from the year 2000 to 2019 which was the time of the present study. The duration 2000 to 2019 was chosen due to being the post PPP period hence covering implementation of such projects. The identified literature, and review findings are presented in Table 1.

A study by [16] in the Czech Republic used a descriptive research design where both the questionnaires and interview schedule was used to collect data. Taking the example of tunnel construction projects, the study established that

Table 1. Reviewed literature.

\begin{tabular}{|c|c|c|c|c|c|}
\hline Study & Title & Methodology & Findings & Conclusions & Challenges/Risks \\
\hline $\begin{array}{c}\text { Špačková } \\
(2012)\end{array}$ & $\begin{array}{l}\text { Risk management of } \\
\text { tunnel construction } \\
\text { projects }\end{array}$ & $\begin{array}{l}\text { - Descriptive research design } \\
\text { - Questionnaires and } \\
\text { interview schedule } \\
\text { - Tunnel construction } \\
\text { projects in Czech Republic }\end{array}$ & $\begin{array}{l}\text { Uncertainties arise from } \\
\text { human \& organizational } \\
\text { factors and unknown } \\
\text { geotechnical conditions not } \\
\text { identified beforehand }\end{array}$ & $\begin{array}{l}\text { Adopt reliable } \\
\text { prediction system } \\
\text { which estimate risk } \\
\text { factors using a } \\
\text { probabilistic model }\end{array}$ & $\begin{array}{l}\text { - Human factors } \\
\text { - Organizational } \\
\text { factors } \\
\text { - Geotechnical } \\
\text { conditions }\end{array}$ \\
\hline $\begin{array}{l}\text { Osipova } \\
(2008)\end{array}$ & $\begin{array}{l}\text { Risk management in } \\
\text { construction projects: a } \\
\text { comparative study of the } \\
\text { different procurement } \\
\text { options in Sweden }\end{array}$ & $\begin{array}{l}\text { - Nine construction } \\
\text { companies } \\
\text { - Surveys and interviews } \\
\text { - consultants, contractors } \\
\text { and project owners }\end{array}$ & $\begin{array}{l}\text { - No iterative method for risk } \\
\text { management } \\
\text { - Risks were high during the } \\
\text { program phase }\end{array}$ & $\begin{array}{l}\text { Parties involved in } \\
\text { executing projects } \\
\text { could cooperate to } \\
\text { work together to } \\
\text { minimize risks }\end{array}$ & $\begin{array}{l}\text { - Time } \\
\text { - Quality and } \\
\text { - Cost related risks }\end{array}$ \\
\hline $\begin{array}{c}\text { Odeh \& } \\
\text { Battaineh } \\
(2002)\end{array}$ & $\begin{array}{l}\text { Causes of construction } \\
\text { delay: traditional } \\
\text { contracts. }\end{array}$ & $\begin{array}{l}\text { - Construction project in } \\
\text { Jordan } \\
\text { - Survey method }\end{array}$ & $\begin{array}{l}\text { - Labour efficiency } \\
\text { - Inadequate experience } \\
\text { among contractors and } \\
\text { consultants } \\
\text { - Owner interference are the } \\
\text { leading causes of delay }\end{array}$ & $\begin{array}{l}\text { Project management } \\
\text { and interaction } \\
\text { between stakeholders } \\
\text { result in project } \\
\text { delays }\end{array}$ & $\begin{array}{l}\text { - Labour efficiency } \\
\text { - Incompetent } \\
\text { consultants } \\
\text { - External } \\
\text { interference }\end{array}$ \\
\hline $\begin{array}{c}\text { Aibinu \& } \\
\text { Jagboro (2002) }\end{array}$ & $\begin{array}{l}\text { The effects of } \\
\text { construction delays on } \\
\text { project delivery in } \\
\text { Nigerian construction } \\
\text { industry }\end{array}$ & $\begin{array}{l}\text { - } 61 \text { construction projects in } \\
\text { Nigeria } \\
\text { - Risk assessment and } \\
\text { evaluation form }\end{array}$ & $\begin{array}{l}\text { Delays had significant } \\
\text { implications for project } \\
\text { execution in the country }\end{array}$ & $\begin{array}{l}\text { Failing to complete } \\
\text { task in time as } \\
\text { scheduled occur } \\
\text { frequently among } \\
\text { contractors }\end{array}$ & - Time related risks \\
\hline $\begin{array}{l}\text { Ke, Wang \& } \\
\text { Chan (2012) }\end{array}$ & $\begin{array}{l}\text { Risk management } \\
\text { practice in China's } \\
\text { Public-Private } \\
\text { Partnership projects }\end{array}$ & $\begin{array}{l}\text { - Structured interviews with } \\
20 \text { managers in the sector } \\
\text { in China } \\
\text { - Comparison using Lyons \& } \\
\text { Skitmore (2004) } \\
\text { questionnaire }\end{array}$ & $\begin{array}{l}\text { - Inadequate risk } \\
\text { management } \\
\text { - High preference for } \\
\text { qualitative risk assessment } \\
\text { - Lack of risk management } \\
\text { tools }\end{array}$ & $\begin{array}{l}\text { Lack of risk } \\
\text { management culture } \\
\text { responsible for lack } \\
\text { of implementation of }{ }_{1} \\
\text { risk assessment }\end{array}$ & $\begin{array}{l}\text { Inadequate training } \\
\text { and tools for risk } \\
\text { assessment and } \\
\text { management }\end{array}$ \\
\hline
\end{tabular}




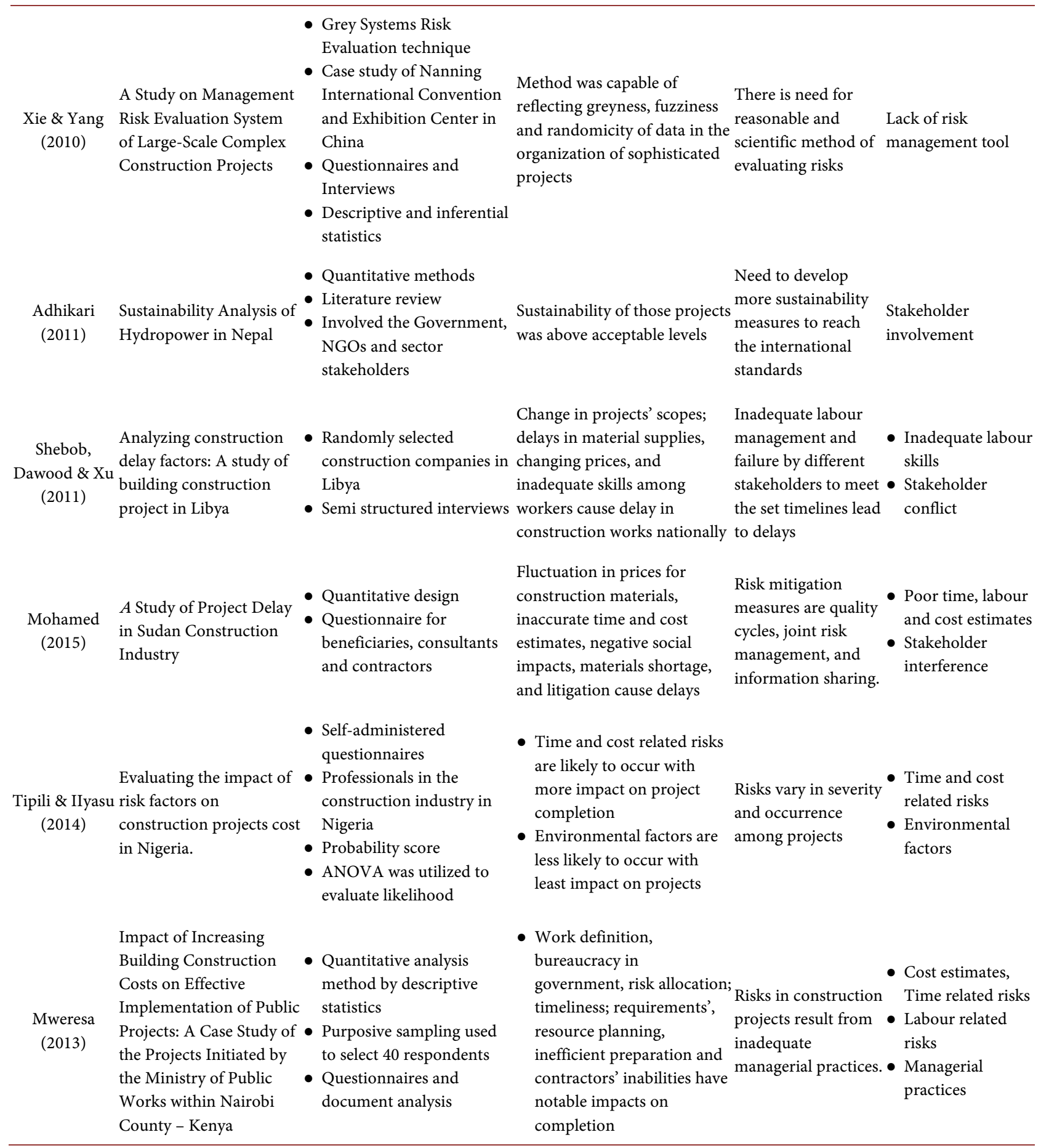

some of the uncertainties emanated from human and organizational factors and unknown geotechnical conditions that were not known beforehand. Spackova [16] proposed the adoption of reliable prediction mechanisms which would estimate those factors using a probabilistic model that does not rely on expert judgments as they tend to be unreliable and biased.

In Sweden, [17] investigated some of the steps that were utilized to minimize 
risks in procurement projects. Osipova [17] noted that construction-related risks significantly impact the construction projects in the country because it affected the quality, time and costs of those projects. However, he observed that how risks were shared was essential to project completion. Osipova [17] undertook to demonstrate the way risks management processes had changed in Sweden. Accordingly, it obtained its data from nine construction companies and utilized surveys and interviews to gather data from consultants, contractors and project owners. The findings showed that there was no iterative method of managing risks among the companies that were included in the study. The risks were high during the program phase, and it was likely to impact project completion negatively. Despite this, the study observed that parties involved in executing projects could cooperate to work together to minimize risks. Osipova [17] claims that risks have great impact on the performance of construction projects because they affect their quality, time and cost. One important thing to note is that the process of sharing risk is determined by the way contract documents are developed.

Odeh and Battaineh [18] evaluated the factors attributable to delays in project construction in Jordan using survey method. They established that contractors see labour efficiency as leading determinant of delays, followed closely by inadequate experience among contractors and consultants. Further, project owners' interference was also attributable to delays. Aibinu and Jagboro [19], who conducted a study on delay factors in projects. With the help of data collected from 61 construction projects in the country, an identification, assessment and evaluation of risk effect of those projects. They established that delays had significant implications for project execution in the country. Similarly, [11] evaluated the methods utilized in china to allocate risks equitably among Chinese PPP projects. The study used comparative methods to analyze this issue, and it identified three types of risks: organizational and coordination, exclusive right and change in law as the most prominent types of risks in those projects. The study was based on computational risk management modelling and focused on proposed risk allocation based on a change in law, competition, organization and coordination risks.

Xie and Yang [20] conducted a study on the practical steps and methods utilized to manage risks in such projects in China. They established various systems of managing risks from Grey Evaluation and used a case study to depict the extent of such measures. Both questionnaires and interview schedule were used. Descriptive and inferential statistics were used for the analysis of data. The result indicated that the method was capable of reflecting greyness, fuzziness and randomicity of data in the organization of sophisticated projects, thereby highlighted the importance of reasonable and scientific method of evaluating risks.

Adhikari [21] conducted a study to determine the sustainability of hydroelectric power in Nepal, India. The quantitative method was utilized to conduct the study and even simplify the main themes. The analysis was based on a literature review developed by the Nepalese government, NGOs, public and private sector 
players in the development of hydroelectric power projects in the country. The parameters that sustained those projects were based on Nepal context. However, the study by [21] faced two main challenges: 1) the data lack some form of reliability because it was collected from different sources, and 2) it was a bit hard to obtain updated information. Despite these challenges, the study concluded that sustainability of those projects was above acceptable levels. Nonetheless, Nepal needed to develop more sustainability measures to reach the international ones. The assessment by [21] focused on the sustainability of hydroelectric power projects but not the effect of the excess costs above budget ceilings influence project implementation.

According to consultants, setbacks in decision making; poor planning and supervision; poor communication; lack of skills among consultants; a lot of time wasted as contractors wait for sample materials and drawings to be approved are some of the factors that delay projects. Shebob, Dawood and Xu [22], who conducted their study in Libya established that change in projects' scopes; delays in material supplies, changing prices, and inadequate skills among workers was among the main factors that delayed construction works nationally. From the owners' viewpoint, those factors included lack of skills among workers; site transfer delay from the owners to the contractor, site modification (office, workshop and lab setup); changes in the material specification.

Mohamed [12] conducted a study to establish the causes of delay in Sudanese construction projects using a quantitative design. A questionnaire administered to beneficiaries, consultants and contractors and comprising of a list of factors that delayed projects was the main tool. Respondents indicated their opinion on 5 points Likert scale. Data revealed that fluctuation in prices for construction materials, inaccurate time and cost estimates, negative social impacts, materials shortage, and litigation were some of the factors that delayed projects. Besides, too much pressure from projects' stakeholders, disputes among participants and declines in revenues were among the risks that were associated with delays in project delivery. Risk mitigation measures were found to include quality cycles, joint risk management, information sharing and Total Quality Management (TQC).

Tipili and Ilyasu [14] sought to determine the likelihood of delays occurring and risk factors for the projects. The purpose was to identify the role of index score rating of major risks on performance of Nigerian construction projects. The study utilized questionnaires which were self-administered by the participants to acquire data from professionals in the construction industry. About 78 questionnaires were issued to target population, but only 58 of them were completed and returned. The probability of score was categorized in three levels namely low, high and medium thereby ANOVA was utilized to evaluate the likelihood of occurrence. The study established that there was disparity in the degree of occurrence among the different groups. Nonetheless, the time and cost related risks were identified as likely to occur more than others and even impact project completion. Environmental factors had the least weight indicating that they were 
unlikely to affect project completion and even had the least impact on projects. Tipili and Ilyasu [14] laid emphasis on probability of risk occurrence and not how the specific risks influence project delivery.

Mweresa [15] investigated the impact of high prices in construction projects. Overall, the study was designed to reveal the major causes of rising construction costs in public buildings, outline guidelines to safeguard the financiers against rising costs as a result of extended preliminaries/time related costs and to identify problems and put in place measures to reduce the increasing building construction costs. The population of the study consisted of contractors, consultants, and clients. Purposive sampling was used to select forty respondents. Questionnaires and document analysis guides were used to obtain data and analyzed quantitatively by descriptive methods in the form of frequencies and percentages. An analysis of the 33 factors that were determined to be significant showed that eight factors, namely work definition, bureaucracy in government, risk allocation; timeliness; requirements' interpretation, resource planning, inefficient preparation and contractors' inabilities had notable impacts on overruns. Most of the projects included in the analysis had delays of between 4.6 percent and 53.4 percent, whereas their excess costs above budget varied from 9.4 percent to 29 percent.

\section{Conclusion}

From the review, the risk factors are mainly as a result of human and organizational factors and unknown geotechnical conditions that were not known beforehand. The risks were high during the program phase, and it was likely to impact project completion negatively. Specifically, project owners' interference was also attributable to delays with the delays having significant implications for project execution. Similarly, organizational and coordination, exclusive right and change in law are also the most prominent types of risks in those projects. In this case, a lot of time wasted as contractors wait for sample materials and drawings to be approved are some of the factors that delay projects. Other factors include lack of skills among workers; site transfer delay from the owners to the contractor, site modification (office, workshop and lab setup); changes in the material specification. Risks have great impact on the performance of construction projects because they affect their quality, time and cost. In this case, contractors see labour efficiency as leading determinant of delays, followed closely by inadequate experience among contractors and consultants. The general remedy to such potential risk factors is adoption of reliable prediction mechanisms which would estimate those factors using a probabilistic model that does not rely on expert judgments as they tend to be unreliable. Thus, parties involved in executing projects could cooperate to work together to minimize risks.

\section{Acknowledgements}

We acknowledge the special service and assistance from the University of Nairo- 
bi Library for support during this review.

\section{Conflicts of Interest}

There are no conflicting interests to declare with reference to this review.

\section{References}

[1] World Bank Report (1993) Housing: Enabling Markets to Work with Technical Supplements. The World Bank, Washington DC.

[2] Alexandersson, G. and Hultén, S. (2007) Prospects and Pitfalls of Public-Private Partnerships in Railway Transportation. Theoretical Issues and Empirical Experience. International Journal of Transport Economics, 36.

https://www.researchgate.net/publication/264872025_Prospects_and_pitfalls_of_pu blic-private_partnerships_in_railway_transportation_Theoretical_issues_and_empi rical_experience

[3] Li, B., Akintoye, A., Edwards, P. and Hardcastle, C. (2004). Risk Treatment Preferences for PPP/PFI Construction Projects in the UK. 20 th Annual ARCOM Conference, UK, 1-3 September 2004, 1259-1268.

https://www.researchgate.net/publication/228470053_Risk_treatment_preferences_f or_PPPPFI_construction_projects_in_the_UK

[4] Mohr, J. and Spekman, R. (2004) Characteristics of Partnership Success: Partnership Attributes, Communication Behavior, and Conflict Resolution Techniques. Strategic Management Journal, 15, 135-152. https://doi.org/10.1002/smj.4250150205

[5] Farlam, P. (2005) Working Together Assessing Public-Private Partnerships in Africa.

https://www.researchgate.net/publication/239601344_Working_Together_Assessin g_Public-Private_Partnerships_in_Africa

[6] Lucey, T. (2005) Management Information Systems. Thomson Learning, London.

[7] Panthi, K., Ahmed, S. and Ogunlana, S. (2009) Contingency Estimating for Construction Projects through Risk Analysis. International Journal of Construction Education and Research, 5, 79-94. https://doi.org/10.1080/15578770902952181

[8] OECD (2010). Private Public Partnerships for Managing the Risks and Opportunities: OECD Regulatory Reform Review of Indonesia Working Group Meeting Jakarta. http://www.oecd.org/gov/regulatory-policy/47377698.pdf

[9] Chileshe, N. and Yirenkyi-Fianko, A.B. (2011) Perceptions of Threat Risk Frequency and Impact on Construction Projects in Ghana: Opinion Survey Findings. Journal of Construction in Developing Countries, 16, 115-149.

https://www.researchgate.net/publication/289178269_Perceptions_of_Threat_Risk_ Frequen-

cy_and_Impact_on_Construction_Projects_in_Ghana_Opinion_survey_findings

[10] Gwaya, A.O., Masu, S.M. and Wanyona, G. (2014) A Critical Analysis of the Causes of Project Management Failures in Kenya. International Journal of Soft Computing and Engineering, 4, 64-69.

https://citeseerx.ist.psu.edu/viewdoc/download?doi=10.1.1.650.2919\&rep=rep1\&typ $\underline{\mathrm{e}=\mathrm{pdf}}$

[11] Ke, Y., Wang, S. and Chan, A. (2012) Risk Management Practice in China's Public-Private Partnership Projects. Journal of Civil Engineering and Management, 18, 675-684. https://doi.org/10.3846/13923730.2012.723380

[12] Mohamed, M.B. (2015) A Study of Project Delay in Sudan Construction Industry. 
Unpublished Master's Thesis, Universiti Tunku Abdul Rahman, Malaysia. http://eprints.utar.edu.my/id/eprint/1619

[13] Mousa, J.H.A. (2005) Risk Management in Construction Projects from Contractors and Owners' Perspectives. MSc. Thesis, The Islamic University of Gaza-Palestine, Palestine. https://www.mobt3ath.com/uplode/book/book-15143.pdf

[14] Tipili, G.L. and IIyasu, M.S. (2014) Evaluating the Impact of Risk Factors on Construction Projects Cost in Nigeria. The International Journal of Engineering and Science, 3, 10-15. http://pmworldjournal.net/

[15] Mweresa, J.O. (2013) Impact of Increasing Building Construction Costs on Effective Implementation of Public Projects: A Case Study of the Projects Initiated by the Ministry of Public Works within Nairobi County-Kenya. Unpublished Bachelor's Project, University of Nairobi, Nairobi.

[16] Špačková, O. (2012) Risk Management of Tunnel Construction Projects. Unpublished Doctoral Dissertation, Czech Technical University in Prague, Prague.

[17] Osipova, E. (2008) Risk Management in Construction Projects: A Comparative Study of the Different Procurement Options in Sweden. Master's Thesis, Luleå Tekniska Universitet, Luleå.

https://www.researchgate.net/publication/270163040_Risk_management_in_construc tion_projects_a_comparative_study_of_the_different_procurement_options_in_Swed en

[18] Odeh, A.A. and Battaineh, T.H. (2002) Causes of Construction Delay: Traditional Contracts. International Journal of Project Management, 20, 67-73. https://doi.org/10.1016/S0263-7863(00)00037-5

[19] Aibinu, A. and Jagboro, G. (2002) The Effects of Construction Delays on Project Delivery in Nigerian Construction Industry. International Journal of Project Management, 20, 593-599. https://doi.org/10.1016/S0263-7863(02)00028-5

[20] Xie, L. and Yang, Y. (2011) A Study on Management Risk Evaluation System of Large-Scale Complex Construction Projects. In: Wu, D., Ed., Modeling Risk Management in Sustainable Construction. Computational Risk Management, Springer, Berlin, Heidelberg, 103-111. https://doi.org/10.1007/978-3-642-15243-6_12

[21] Adhikari, D. (2011) Sustainability Analysis of Hydropower in Nepal. Unpublished Master's Thesis, Helsinki Metropolia University of Applied Sciences, Metropolia. https://www.theseus.fi/bitstream/handle/10024/38475/FINAL+THESIS.pdf;jsessioni $\mathrm{d}=3 \mathrm{EE} 86 \mathrm{~F} 6530 \mathrm{FCB} 6 \mathrm{~B} 400 \mathrm{FF} 084 \mathrm{D} 7030 \mathrm{~F} 583$ ? sequence $=1$

[22] Shebob, A., Dawood, N. and Xu, Q. (2011) Analyzing Construction Delay Factors: A Case Study of Building Construction Project in Libya. Proceedings of the 27 th Annual ARCOM Conference, Bristol, 5-7 September 2011, 1005-1012.

http://www.arcom.ac.uk/-docs/proceedings/ar2011-1005-1012_Shebob_Dawood_X u.pdf 